\title{
Can Teaching Be Taught? or Are Real Teachers Found or Made?1
}

\section{Max van Manen}

Professor

Department of Secondary Education

University of Alberta

During my Dutch high school years, and at the Pedagogy College in the Netherlands in the 1960s I became familiar with the phenomenological and hermeneutic writings of Dutch, German, and French educators, philosophers, and novelists. Especially the phenomenological writings of the pedagogues M.J. Langeveld, N. Beets, the psychiatrist J.H. Van den Berg, the psychologists F.J.J. Buytendijk and H. Linschoten, as well as, of course, French authors like J.P. Sartre, S. de Beauvoir, A. Camus, M. Merleau-Ponty and the German scholar O.F. Bollnow made a great impression on me. After emigrating to Canada I further developed this interest in my graduate studies at the University of Alberta encouraged by the thoughtful support of my gifted supervisor Ted Aoki.

As an assistant professor at the Ontario Institute for Graduate Studies in Education from 1973 to 1976 I launched the beginnings of a phenomenological research writing course. The European literature on human science in education had paid little attention to its own methodological practice. Therefore, in order to develop a teaching and research program, I have aimed to explore the unexplicated methodological themes and practical approaches of human science work by the above named European educators and psychologists, and by studying philosophers such as M. Heidegger, H.-G. Gadamer, M. Foucault, and E. Levinas, while relating this work pedagogically to contemporary philosophic sources and to new North American developments in education and the social sciences.

Since rejoining the Faculty of Education at the University of Alberta in 1976 my research involvements have continued to focus on the articulation and application of a reflective writing approach for understanding the life worlds of adults and children in a hermeneutic phenomenological fashion. Especially my continuing contacts with the younger generation of Dutch and German scholars such as Ton Beekman, Dirk Imelmann, Bas Levering, Wilfried Lippitz and the collaborations with colleagues and students at the University of Alberta have been inspiring to my personal efforts. Recent publications include The Tone of Teaching (1986), Researching Lived Experience: Human Science for an Action 


\section{University of Alberta}

Sensitive Pedagogy (1990), and The Tact of Teaching: The Meaning of Pedagogical Thoughtfulness (1991).

For my recent text The Tact of Teaching I asked the publisher to use for the cover the picture "Grandfather and Grandson" by the Italian painter Ghirlandajo who lived between 1448 and 1494 . This painting has played a minor role in prompting important questions about the theories of the concept of child and childhood through the ages-particularly the claim by Philippe Ariès and other social psychologists and historians that the affectional relation between adults and children is only a recent cultural phenomenon, dating to Rousseau's discovery of the child in the 18th century.

When I asked my 12-year-old son Mark what he thought the boy and the grandfather were thinking Mark assumed, of course, a natural continuity with his own experience. He said: "The boy probably wonders how his grandpa got all those warts on his nose." But when he saw my face he quickly added, “No, no, I'm just kidding, I think that the boy is telling his grandpa something that he likes. They seem to be sharing a story or

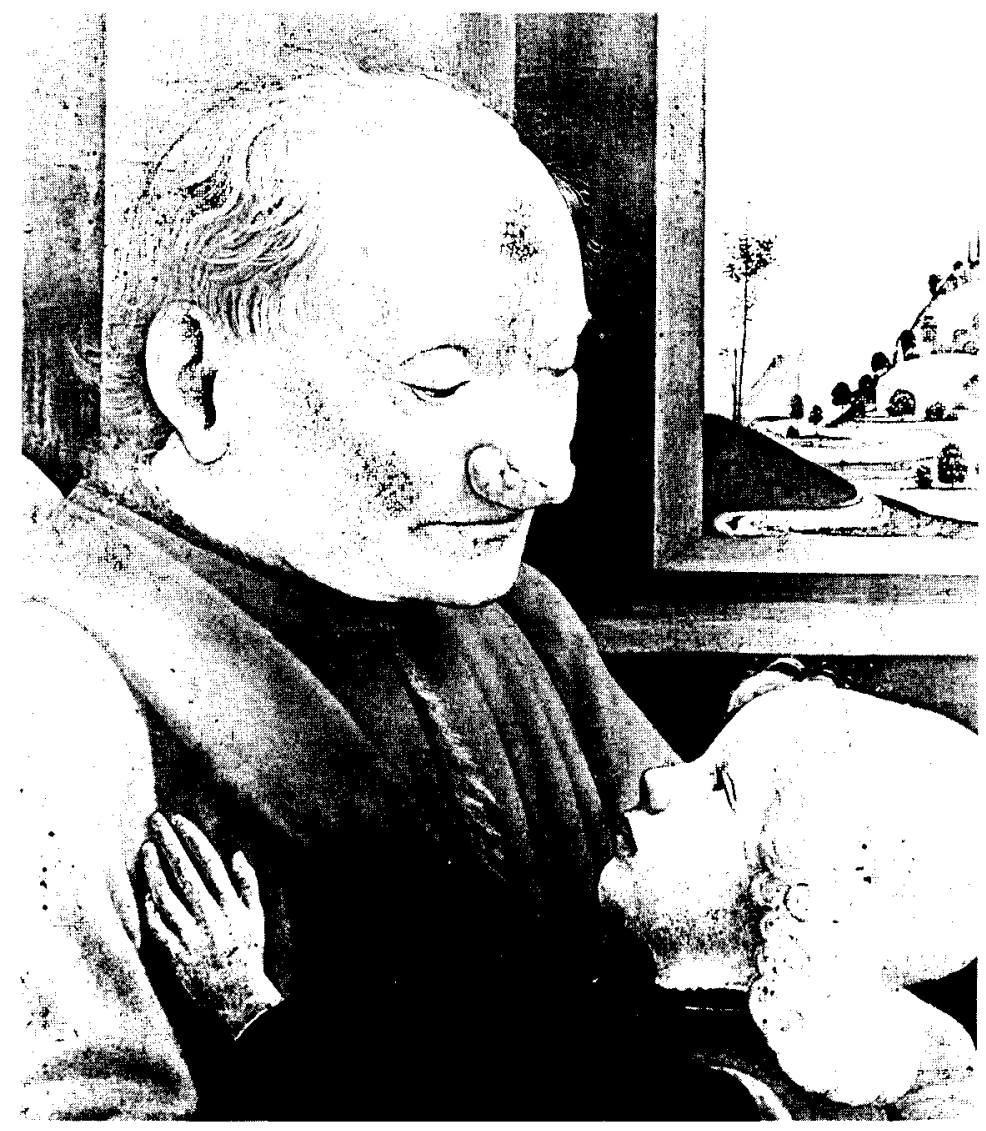


something; or maybe the boy is just about to give his grandpa a hug." Then, after pause, he asked: "Are those really warts on his nose? How do you get those?" So I said, of course, "That's what happens, Mark, if you do not eat your broccoli."

Mark's interpretation goes in the same direction as the German scholar Klaus Mollenhauer ${ }^{2}$ who interprets the painting this way:

The scepsis of the grandfather and the glance of the child-questioning and full of trust $\rightarrow$ stand in a certain relation to each other. It expresses an open, uncertain future, and a waiting for knowledge that is passionately desired, to become "grown-up." Between child and grandfather there lies a life of development, learning, and formative growth. In their loving relation they are together and true to each other, but with respect to the future, that they anticipate in accordance with their own abilities and possibilities, they are separated from each other. $(1983$, p. 95)

I hope you would agree that the caring atmosphere of the personal relation between the elder and the child is almost viscerally felt. I would suggest that we think of this relation as the source of the meaning of pedagogy. And that we need to try to understand the notion of pedagogy not as we find it currently gaining usage among North American theorists, but rather as we find it used in the tradition of European educational thought and teacher education practices.

A second painting portrays another example of the living relation between adults and children. This painting by Jan Steen is called "Sinterklaas Feest", the "St. Nicholas Feast". I suggested it as an alternative to the publisher. Jan Steen, a contemporary of Rembrandt, was a famous artist who was unique in that he painted many ordinary life scenes of everyday Dutch folk in the 1600 s. This is a typical Dutch family scene. On December 5, St. Nicholas brings presents to those children who have been good, such as the little girl in the front. The crying boy on the left must now atone for his past pranks and trickery. His sister smugly shows his empty shoe to the others while his younger brother gleefully points a finger. But the grandmother in the back gestures to the disappointed boy to console him with a surprise that has been kept secret for him.

Look how masterly the various actions, reactions, and relations of adults and children are portrayed. I would like to draw your attention to the busy immediacy and spontaneity of the actions of the adults and children. It is this busy immediacy that speaks to the question of the nature of pedagogical action and reflection. It illustrates nicely how living with children, even in situations of planned family ceremony, is full of unpredictable reactions and contingent circumstances. While life in presentday homes and schools may be less rambunctious than portrayed in this 16th-century Dutch home, the interactional relations between adults and children are essentially not dissimilar. Families may have changed, schools may be differently patterned, but in our everyday dealing with 


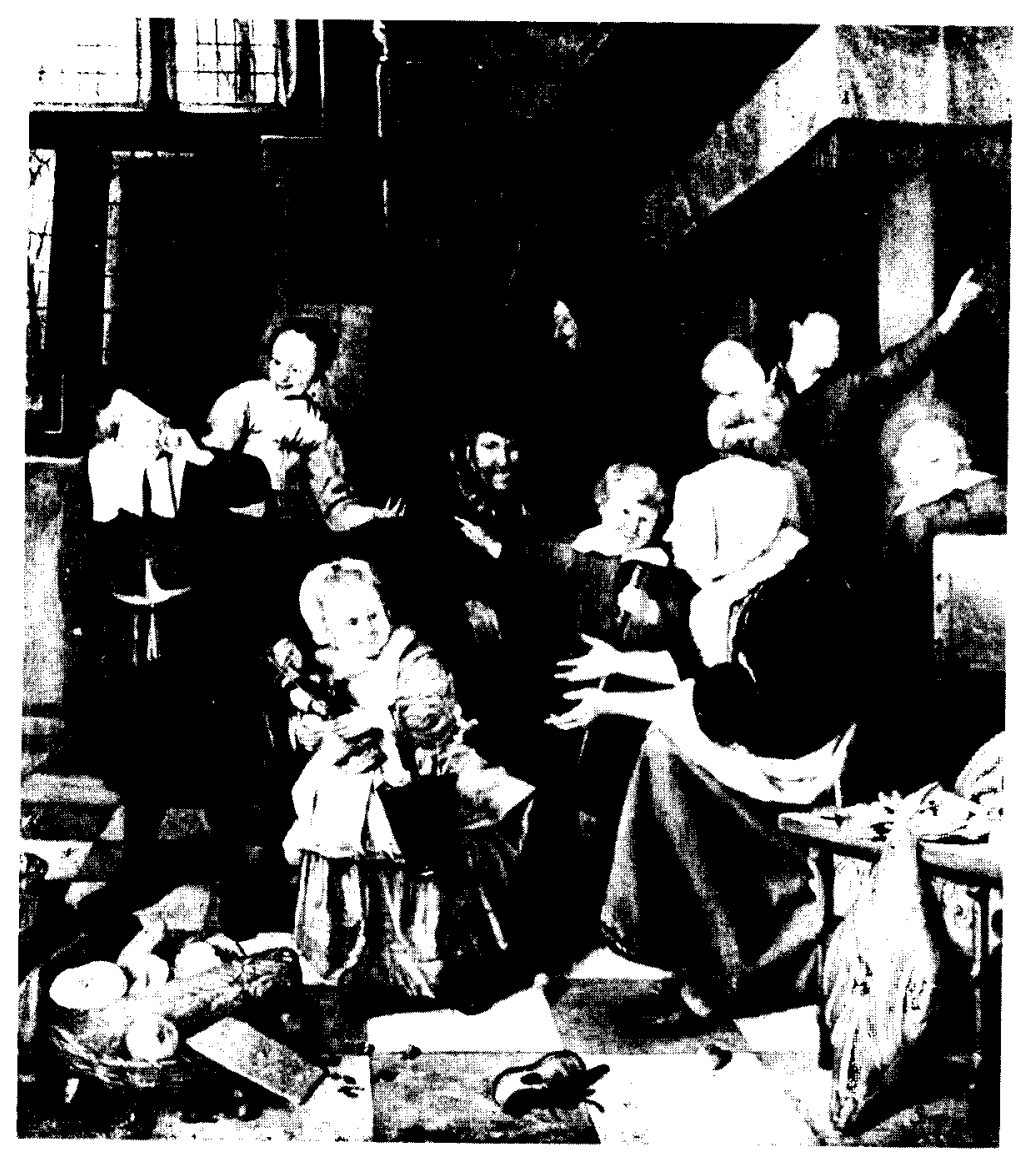

children no moment is completely foreseeable, no individual response or action is ever quite predictable, no child's experience is ever quite the same.

Jan Steen's picture is so disarming because (in spite of the many centuries that separate us from this household) we recognize the same rush of human exchanges and the same range of emotions. His painting is intriguing because our response tends to be pedagogical in that we wonder about the nature and aptness of how adults deal with children in this scene.

Having raised the issue of pedagogy and the special notion of the pedagogical relation, I would like to start with a question that is admittedly rhetorical, but that is intended to bring further forward the issue of the nature of pedagogy in the life of teachers. The question is this: Suppose someone had learned all theories of child development, knew all curriculum methods, and had learned all techniques of instruction-isn't it strange that this person can nevertheless be a poor teacher? 
Being a parent with various educational responsibilities I sometimes feel that I am living in a house with many windows, each window offering not only an entirely different view, but also a changing atmosphere. For example, the window of the education faculty is pleasantly bright and promising as I see new teachers entering the sunny fields where children play. The window of the teacher association or union is also very positive, almost artificially so. The view looks a bit like an overconfident propaganda poster of healthy, strong, clearheaded, and committed men and women laboring together on a lofty task with jubilant children at their sides. The window of the government department of education seems foggy and dirty, hard to see through. It is hard to see any children from this window at all. Cleaning seems to make the view even more smeared, and besides some of the dirt seems to be caught between the window panes. Then there is the parental window. The view from here resembles a crazy midway. We watch our children climb daring and sometimes dangerous rides. We wave encouragingly. But look: there are many ride attendants who seem inattentive, incapable, indifferent, or too busy fixing things to notice the mood, the abilities, and reactions of the children. What is even more worrisome, some rides seem to have no attendants at all.

I have two children, aged 10 and 12 , in grade school and I am constantly watching schools, teachers, and children from this parental window showing me things that hitherto I did not see from the other windows. My wife and I are both teachers and we often wonder: How is it that some teachers seem so good while many others flounder, are insensitive to the ways that children learn, or seem simply indifferent to the pedagogical impulse-the impulse that made Northrop Frye talk about the education of young people as the original, most important ministry of all human existence? So as parent and as university teacher I sometimes wonder: What is so difficult about teaching? And: Why don't all people we train become "real" teachers? Although I do not claim to have the answers to these questions, I would like to offer some considerations that may help with answers.

My first point is that the life of teaching is in a curious sense contingent and does not resemble the kind of rational practice that is reflected in many, if not most, teacher education texts and programs. From their perspective, inexperienced teachers soon discover that there is a quality of irrationality about teaching children. The naive or new teacher is sometimes surprised that this quality of contingency is so totally at odds with the degree that the teacher feels primed to teach the lesson. The novice teacher may have thought that, as long as you are very well prepared, you can just walk in and teach the material. And as long as you knew it all and expressed it all the task would be done. The measure of how well it would have been done would depend on how carefully you had planned and thought through exactly what you would need to say and do, 


\section{University of Alberta}

and on the extent to which the students caught on to what you were trying to do.

To be sure, a well-planned lesson greatly increases the odds of a successful class. But, not unlike comedians on their first-night performance, novice teachers soon realize that their preparations may fall flat, lessons become ineffectual, and the teaching-learning situations often lack the sparkle and inspiration that they had hoped for. Stand-up comedians have a word for the test of an act; it is called "stand and deliver"-the interpretive ability to deliver one's lines in fine attunement with the mood of the audience. Like Jaime Escalante in the movie Stand and Deliver, good teachers know that there is an interpretive dimension to teaching that is not just incidental to the life of the classroom but that belongs to it essentially.

The job of teaching is even more demanding than that of stage acting since teaching is not just a rehearsed performance, but a dynamic interpersonal, interactive process; unlike stage actors, teachers can never be sure of their next lines. Teaching requires the improvisational skill of instantly knowing how to interpret ever changing situations, a sense of timing, immediately knowing what goes on with a child, what to do, how to present something, how to hold back, how to create the right tone in a class. Teachers who do not possess this special skill tend to become task masters or lecturers. Lecturing means "delivering" a prepared text in front of a silent audience and it matters little whether the audience counts 20,50 , or 500 .

Good teachers experience classroom events with students as something that continually changes their actual plans and expectations. In the dynamic processes of teaching children, things rarely go according to plan. Teachers who nevertheless try to stick to their plans (rather than continually reminding themselves of the deeper pedagogical intents) inevitably discover how shallow their pedagogical intents or reasons really are.

One answer to the practical demands of teaching has been the notion of the teacher as a reflective practitioner. It posits that teaching is really a process of reflective decision making. The notion of the reflective practitioner says that the teacher is a professional who operates within an educational domain in a manner that is comparable to medicine or engineering.

My sense is that the notion of reflective teaching may be misleading. There are several reflective dimensions in teaching: (a) reflection before action, (b) reflection on action, (c) reflection in action.

I have no issue, of course, with the first two types of reflection: Reflection before action enables us to deliberate about possible alternatives, decide on courses of action, plan the kinds of things we need to do, anticipate the experiences we and others may have as a result of expected happenings 
or of our planned actions. Reflection on action, or recollective reflection, helps us to make sense of past experiences and thus gain (new or deeper) insights into the meaning of the experiences we have with children. Phenomenological reflection would belong in this category.

However, the third type of reflection has received most of the attention of teacher educators. Reflection in action supposedly allows us to come to terms with the situation or problem with which we are confronted in the here and now. But, inevitably, reflection-in-action involves a moment of detachment. The more careful this decision making process is, the greater the degree of detachment and interruption. Nevertheless, stop-andthink type of reflection permits us to make decisions virtually on the spur of the moment. For example, a medical doctor, after having examined a patient, commonly will ask the patient to sit down while he or she steps back, as it were, writes up the diagnosis, and decides whether the patient should try this or that medication, or maybe should go for a lab test, or, alternatively, should maybe see a medical specialist instead. However, teaching very rarely allows for any such reflective distancing in the midst of dealing with children. And yet it is on this model of reflective practice that the idea of teaching as constant decision making is based.

In contrast, I would like to draw your attention to the pedagogical moment of teaching itself because this interactive experience is characterized by a very different type of reflectivity. The active moment of teaching requires not a form of reflective decision making, but a certain thoughtfulness or active mindfulness. It is this practical thoughtfulness, this process of thinkingly acting, that I would like to discuss with the notion of tact. While we are interacting (talking, gesturing, listening, playing, working) with children, we usually do not have time or opportunity to reflect on our experience as it is happening. Probably much of our pedagogical interacting with children is made up of an ongoing "rush" of pedagogical situations and circumstances. In the immediacy of our actions, reflection does not occur in moments of interrupted stop-and-think action; neither does it occur parallel or side-by-side with our actions. In other words, instant action is not usually produced by rational reflection. And yet this interactive experience may be thoughtful (rather than being mindless, artificial, routine, or merely impulsive).

So, then, what beginning teachers apparently must learn is that the contingencies of the moment, the mood of the class, the dynamics of personal relations, the readiness of students make demands for a certain improvisational competence, a ready fitness on the part of the teacher. Jay looks puzzled, Anne needs to go to the washroom, Rob seems unable to concentrate, and Mary is finished already, Sook is anxious about something, Jan does not know what to do, Jill produces a magnificent piece of work, Kazim is talking too much, Tammy suddenly gets the hiccups, Jo cannot find her books, Steve starts a fight, Henry walks aimlessly through the room. From one moment to the next, preparations 


\section{University of Alberta}

may go amiss, assignments may create difficulties, group work may lead to unexpected issues, class discussions may stall or drift, presentations may falter, a conflict may suddenly explode, and there may also be interruptions from outside the classroom. Instructional techniques or discipline principles are not very helpful because they always seem cast in a rational-technical frame, a frame that is too sluggish, too encumbering, and too inflexible to deal with the immediacy of living human processes in classrooms.

And now I arrive at my second point: teaching does not require only an improvisational readiness and pedagogical understanding of children. This improvisational ability is structured like a moral intuitiveness. Indeed pedagogy could be defined as the process of actively and reflectively distinguishing between what is good or appropriate and what is not good or less appropriate for children. "Whether we like it or not," said Buber, "we always educate toward something; it depends on us whether that something is something desirable or undesirable." A teacher who is more than a mere instructor is constantly required to know instantly what is pedagogically the "good" or "appropriate" thing to say or do. Pedagogical acting and pedagogical understanding go hand in hand.

If we were to articulate what are some of the characteristics of the good teacher we would realize the extent of the normativity of pedagogy. In my list of a pedagogically talented man or woman there are many items that seem to fall completely outside the more common domain of classroom management skills or teacher competences that we can train for in people. I believe that these qualities have more to do with the nature of pedagogy itself. Here are some of these qualities :

A real teacher possesses

1. A sense of vocational animation-periodically we all must get in touch with why it is that we got into education in the first place.

2. A love or caring for children-I do not think that you can truly understand children if you do not like them.

3. A reliable personality-a teacher must be a person that young people can count on.

4. A deep sense of responsibility for children-an educator must feel responsive to the needs and vulnerabilities of children.

5. A belief in children-there is nothing more powerful in a child's learning than the motivating trust that your teacher thinks the world of you and believes in you.

6. Openness-a good teacher should be constantly prepared to see things from different perspectives; good teachers are experts of perspective. 
7. A thoughtful maturity-thoughtful maturity includes a certain understanding or wisdom of what goes on in the world.

8. A sensitivity toward the child's subjectivity-we must always ask ourselves what the child's experience is like.

9. An interpretive intelligence - this means pedagogically understanding the meaning of children's experiences and to be patient about their individual developments and needs.

10. A determined resoluteness-a good teacher is not wishy-washy in dealing with young people in classrooms.

11. Moral fiber-or the willingness and courage to stand up for something.

12. An active hope-children need our confident support in the face of prevailing global, ecological, and social crises.

13. Humor and vitality-teachers must be able to make things light so that children are able to gain new perspectives on them.

14. Subject matter experise - of course, a good teacher must have a passion for knowing and learning the mysteries of the world: minimally this means that they should know and embody what they teach.

15. A selfless sense of generativity - this involves giving of oneself; unfortunately sacrifice is an unpopular and neglected notion nowadays.

This kind of list proves for me that to be an educator is an incredibly demanding task. To be a real teacher involves more than having acquired a set of instructional skills and curriculum competencies. A real teacher is a complex person in a normative pedagogical sense. Of course, these pedagogical criteria are a tall order for any human being. But underlying this image of the real teacher lies a crucial question: Does a person who lacks any one of these qualities or abilities really possess the pedagogical fitness required for educating young people? The third point I would like to dwell on is how much of educational knowledge is cut off from lived experience. Literacy has provided human culture with the possibility for deep and rich traditions, information networks, and printed knowledge sources, but literacy also has shifted experiences from the body to the mind, has robbed us of sensory experience by substituting text for lived experience. Understanding - such as understanding of children-has "gone to our heads," so to speak, has become "sense-less." Knowledge that is aimed at the head atrophies the body and causes swellings of the head in more ways than one. We need to ask how knowledge forms mediated by texts can still somehow speak to our body as well as our head, or better, how educational knowledge can be synchronized with what Merleau-Ponty calls the body-subject.

In life some pedagogical qualities seem to emerge mysteriously in many people once they have children and become parents or teachers. In a 


\section{University of Alberta}

lighthearted but apt manner the author Anne Tyler expressed this mystery well in the novel The Clock Winder (Burms \& de Dijn, 1988). The young woman Elizabeth, who is the main character of the novel, has never cared about children. But now she tells Mrs. Emerson, her employer, how it happened that she decided that she must leave and become a teacher instead. She says:

I was leaning out the window watching a parade go by. There were people crammed on both sidewalks, mothers with babies and little children, fathers with children on their shoulders. And suddenly I was surprised by them. Isn't it amazing how hard people work to raise their children? Human beings are born so helpless, and stay helpless so long. For every grownup you see, you know there must have been at least one person who had the patience to lug them around, and feed them, and walk them nights and keep them out of danger for years and years without a break. Teaching them how to fit into civilization and how to talk back and forth with other people, taking them to zoos and parades and educational events, telling them all those nursery rhymes and word-of-mouth fairy tales. Isn't that surprising? People you wouldn't trust your purse with five minutes, maybe, but still they put in years and years of time tending their children along and they don't even make a fuss about it. Even if it's a criminal they turn out, or some kind of failure - still, he managed to get grown, didn't he? Isn't that something?

Now, you or I may also have been watching the same parade and the same parents and children. We may even have had the same thoughts as Elizabeth and yet we may not have been touched in the same way that prompted Elizabeth to leave her employer.

The philosopher Wittgenstein once made a little noticed distinction between two levels of understanding: between understanding the meaning of something, and being stirred or touched by something in a way that is consequential for one's actions or state of being. ${ }^{3}$ For example, on the one hand, one may be able to understand the words, the semantic meaning, of a poem but not feel addressed or stirred by that meaning. And, on the other hand, we may be able to understand a poem, a story and feel that somehow this poem, story, or event is actually speaking or making an appeal to us. It speaks to our body-mind. Wittgenstein argued that the essence of human meaning is not just being able to understand meaning on the first level, but that, on the second level, one must be able to be touched by something of which one realizes that it could, in another sense, remain meaningless. The scene of the parade touched Elizabeth in her orientation to the meaning that children may have in the life of adults and in her own life. Seeing the parents and the children at the parade stirred a certain thoughtfulness in her-like a poem, it spoke to her in more than a mere intellectual way.

My fourth point is that the technical rational language into which teachers are socialized does something to their minds and affects their relation to their bodies and their emotions. It objectifies and forces into rational 
frames what are otherwise uniquely personal and idiosyncratic styles, moods, interactions, relationships. The objectifying force of educational language tends to redefine the intimacies of our pedagogical relation with our children and they tend to disincarnate the body knowledge we have of our pedagogical responsibility to them.

This objectifying language reflects a kind of rationality that shifts personalized interactions into the sphere of the impersonal and that is unresponsive to the many immediate demands that children continually make on teachers who otherwise are attentive to them. It is very difficult to maintain a pedagogical relation with students individually or collectively as a class when everything militates against teachers knowing their students, having a personal view of them, and being personally involved in learning experiences.

An example of the kind of rationality that is imposed on teachers is exemplified by pronouncements such as those made by politicians that we can improve the productivity of teaching, the management of learning, as well as the economy of the state by more frequent testing and by focusing on outcomes. ${ }^{4}$ But testing itself will improve neither the education nor the performance of children. Dinning seems to want to get at teachers via more test experiences for children. More testing may in fact amount to bloodletting - reducing rather than improving healthy learning experiences of education. Already presently many junior and senior high school teachers and students are caught up in the learn-for-the-test cycle. In many schools, more time seems to be spent on preparing for tests, testing, and in-class student marking of tests than on teacher involvement with actual student work and student learning activities and difficulties. The point is that time spent on testing is largely time lost for learning. My son has only been in junior high school two months and, although his school is small and has a good reputation, already he has learned that if it is not on the test then it must be unimportant and it can be ignored. My fear is that soon he will be like many high school students who only will learn or do homework if it counts for a test or a mark. In other words, something fundamental will have changed in what it means for him to understand, know, or learn something.

A son of a recent immigrant and colleague of mine was early in the year transported from a European to a Canadian junior high classroom. After about three weeks the mother asked about school and the boy said lightly, "Oh, we aren't doing any work yet. We are still doing tests." Later, after about two months, he seemed a bit more troubled: "It is strange, Mom; we are still just doing tests and not any work at all." Of course his mother asked him what he meant by work and the son said "things like projects and writing and research and discussions and presentations." A few weeks later he began to complain to his mother: "If teachers are so busy with assigning and marking tests, then I wonder why they don't just give us the book, send us home and make us come back on Fridays to do the 


\section{University of Alberta}

tests." When the mother asked a teacher about this state of affairs the teacher explained that there are four report cards to be filled out and that she has a hard time getting enough marks assembled to justify her grades.

Now from this anecdote arise several issues having to do with the possible difference of pedagogical style in certain European and North American schools, with teacher autonomy, and with the objectifying language of accountability, with what it means to learn something, and measuring student growth. But I cannot pursue these issues here.

Summing up thus far, I have argued that training teachers is difficult because teaching is difficult for several reasons: First, because teachers are constantly busy and they continually have to improvise in situations of contingency. Second, teaching children is difficult because teachers continually have to actively distinguish between what is good or appropriate and what is not good or less appropriate for particular children in particular situations. Third, I have suggested that teaching is difficult because it is easier to prepare the head than the heart and the body-subject in teacher education or professional development activities. Fourth, at the heart of all education lies the pedagogical relation. And this pedagogical relation is difficult to research since it resists all systematization by objectifying language or technical rationality. In the real world pedagogical relations tend to be driven by intuitive, emotive, immediate, informal, local, personal, or unsystematic forms of knowledge. I conclude this summation by suggesting that we need to recover or invent a pedagogically sensitive language that recognizes the improvisational, normative, embodied, and pedagogical essence of good teaching.

So with my fifth and last point I address these four difficulties. I would now like to turn your attention to an obscure, almost forgotten speech delivered by Johann Friedrich Herbart soon after obtaining his doctoral degree in $1802 .^{5}$ In this very first lecture on education Herbart made a statement that has remained rather unnoticed but that I find most provocative. He said, "The real question as to whether someone is a good or a bad educator is simply this: Has this person developed a sense of tact?"

When I discovered this speech a few years ago I had already explored the notion of pedagogical tactfulness to a considerable degree. Therefore, I found it especially striking how Herbart decribes tact in terms that address the four difficulties of teaching and teacher education that I have discussed thus far. For example, Herbart points out how tact is basic to the process of making instant judgments and quick decisions. And while his views were already tied up in a more mechanistic conception of the relation between knowledge and life, he saw that the strength of tact consists in the ability to deal with unique situations, and of circumventing the alienation between theoretical intellectual knowledge and immediate practical action. Moreover, Herbart suggested that tact relies 
more on feelings, in other words, lived experience, and less on abstract knowledge.

But, strangely, after this lecture Herbart never again mentions tact in his work as far as I know. Did he simply forget to develop this theme in his later work? Or did he regard the requirement for tact in teaching so basic, so self-evident, that it was not worth dwelling on?

At any rate I feel that the notion of tact offers a language for understanding the meaning of teaching and learning that is pedagogically powerful and sensitive to human relations and interactions. I am not suggesting that with the idea of tact we have discovered a new skill that teachers should acquire, but rather that the notion of tact may bring into view aspects of pedagogical thoughtfulness and action that are already present in everyday life and that have always been vitally at work in many classrooms. Ironically many of our educational policies, theories of teaching, and curriculum approaches tend to defeat rather than strengthen pedagogical thoughfulness and tact in teachers.

Teachers who have a high degree of pedagogical tact distinguish themselves by being able to say and do just the right things with students in situations that are always particular, sensitive, always unique, never quite the same. The notion of tact is intriguingly ambiguous. When we think of a person as being tactful we tend to refer neither primarily to an intellectual scholarship nor primarily to something practical. And this is how tact offers a solution to the usual polarization and traditional tension between theory and practice. Someone may have great scholarly knowledge of child psychology but be absolutely clumsy with children. Or someone may have great knowledge of reading theory but ineffective in helping children learn to read. But when we say that a person has tact, then we amibiguously refer to the person's thoughtfulness as well as his or her practical behavior. Tact alchemizes in a powerful way thoughtfulness with action, sensitivity with insight, feeling with knowledge, emotion with understanding.

It may be helpful to offer some background comments on tact in human relations. ${ }^{6}$ Tact derives originally from music. In music, Takt is German for the "beat," the pulse underlying a musical work-this rhythmic beat is the heart of music. With baroque musicians such as Bach, Vivaldi, and Handel, the beat was quite vigorous or even mechanical, not unlike the role of the rhythm section in jazz, whereas with later classical and romantic composers such as Haydn, Mozart, Beethoven, Liszt, and Brahms, the beat that organizes the music became more subtle, retreating somewhat and less everpresent to the ear.

To illustrate how up-front the beat was in the earlier period, there is a story about Jean-Baptiste Lully, the French composer and conductor, who died of blood poisoning in 1687 when he accidentally stabbed himself in the foot with his stick while beating time during a musical perfor- 


\section{University of Alberta}

mance at the court of the French King Louis XIV. Later the conductor's baton became a small stick to wave rather than beat the rhythmic intricacies carrying the melody of a musical piece.

Anyway, it was this new phenomenon of subtlety and holding back in the rhythmic quality of music that caused the French philosopher Voltaire around 1769 to speak of tact when he noticed how some people are capable of striking a special tone in their interactions with others. A tactful person seems to affect or influence others in ways that are often strangely indirect and yet powerful. A tactful person does not manipulate or "make someone do something" but somehow lets the other person do it himself or herself. In this sense it is worth repeating Heidegger's often quoted statement that true teaching is not making learn but "letting learn."

The term tact derives from tactile, which literally means physical touch. But interestingly, in everyday life tact carries the ambiguous sense of a nonphysical influence or effect of one human being on another. Tact is neither intrusive nor aggressive. Often tact involves a holding back, a passing over something, which is nevertheless experienced as influence by the person to whom the tactful action is directed. Unlike notions such as "etiquette" in social affairs and "strategies" in teaching, the strange thing about tact is that there are no rules to follow for being tactful. And since there are no rules for being tactful, we cannot program for tact in our curricula or lessons. Tact is unplannable because it is impossible to reduce tact to a set of techniques. And yet, of course, tact is not unruly in that it is not whimsical, arbitrary, or whishy-washy.

Tact is very much a form of knowing that involves the practical body and not just our verbal behavior. How does pedagogical tact manifest itself? I have described how pedagogical tactfulness manifests itself in everyday life with children as openness to the child's experience, as attunement to subjectivity, as subtle influence, as holding back, as situational confidence, and as improvisational gift.

What does pedagogical tact do? When we observe how tactful teachers act with children, then the implicit moral or normative dimension comes clearly in view. Such teachers tend to be sensitive to the vulnerabilities and personal space of children. They have an eye for what is unique, good, and potentially strong in particular students.

How does pedagogical tact do what it does? As we examine how tact operates in individual educators, then we see that, of course, tact has to do with verbal communication. But, importantly, tact is also mediated through silence, the eyes, gestures, and by way of the special atmosphere and personal example that the educator stylizes in his or her being.

Let me, by way of example, briefly speak to the way that tact is mediated by speech. Because even our verbal behavior in teaching can evoke a tactful climate or sphere that Muth $(1982$, p. 30) calls "the speech 
climate." For example, there is the teacher who says: "Now I want you to take out your book ... I want you to turn to page 87, but I don't like to hear any talking!" Another teacher says: "It seems that we are ready for a change of pace. This may be a good time to discuss the story. Let's turn to page 87."

Both kinds of talk we meet frequently in the classroom. What are some of the implications of the speech climate created by the way that these teachers address their students? The difference between the first teacher and the second is that the first teacher places himself or herself at the center ("I want you to turn to page 87"), the second teacher starts from the situation of the students while drawing himself or herself into the relation that the students have with the text of the curriculum ("Let's turn to page 87"). Even though we do not know anything else about these two teachers, we do sense a difference in tone with which each teacher addresses the children. In the case of the first teacher there exists a certain distance between teacher and students, the teacher's speech seems to reflect a management attitude of "I want you to do this, do that" toward the class. In contrast, the second teacher seems to establish contact with the children, the speech reflects engagement, connectedness, relationship. So while the first teacher speaks with heavy employment of the first person pronoun "I" the irony is that it is the second teacher who, while refraining from frequent first person pronouns in his or her talk, creates a speech climate of personal in-touchness.

Rightly or wrongly much school time is filled by the teacher's voice. And, of course, the voice is a primary means of contact between human beings. That is why it is so important to realize of what a miraculous variety of inflections, timbres, and tonal qualities the voice is capable. A voice can be harsh or gentle, patronizing or respectful, arrogant or modest, belittling or encouraging, indifferent or caring, depressing or uplifting, sour or joyful, agitating or calming, and so on. After many years you may still remember the special quality that a significant remark of mother, father, a teacher, a friend, or a lover left you with-even if you can no longer recall the exact words that were spoken. It is the tonality that touched you, and it is the special atmosphere created by the voice that you remember. We all have been in situations where we became irritated by a discontented, a grating, or a whining voice. Such a voice stimulates us to rebel and resist. In contrast, a gentle or humorous remark can stir us to become more agreeable and suddenly see things in a new light. In both cases it is not just the words themselves that have such effect. It is also the climate created by the voice that makes the difference. The same words spoken differently can have the opposite effects.

I believe that we can create a climate for more thoughtful and tactful pedagogical lives, that our actions can be made more thoughtful through the special process of recollective reflection on significant experiences. For this we need to see that pedagogical knowledge is not only a cognitive 


\section{University of Alberta}

affair but that it must learn to find symbolic forms that can speak undividedly to our head and our heart, to our cognitive as well as to our embodied self.

If the question is: What is the composition of pedagogical tact? What enables tact? I would distinguish four abilities.

First, a tactful educator has the sensitive ability to interpret inner thoughts, understanding, feelings, and desires from indirect clues such as gestures, demeanor, expression, and body language. Tact involves the ability to see through motives or cause and effect relations. Such a teacher is able as it were to read the inner life of the young person.

Second, tact consists in the ability to interpret the pedagogical sig. nificance of the features of this inner life. This means knowing how to interpret, for example, the significance of sadness, shyness, frustration, interest, difficulty, tenderness, humor, discipline, embarrassment in concrete situations with particular children or students.

Third, an educator with tact appears to have a fine sense of standards, limits, and balance that makes it possible to know almost automatically how far to enter into a situation and what distance to keep in individual circumstances.

Fourth, a tactful teacher seems to have the ability of instantly sensing what is the right or good thing to do on the basis of perceptive pedagogical understanding of children's nature and circumstances. This moral intuition is predicated on the practical requirement of the means and ends of education that the teacher must constantly be able to distinguish between what is appropriate and what is not appropriate for a student or a group of children.

Let me give an example of this fourfold complex and insightful sensitivity of tact in teaching. Northrop Frye was revered among his students as an outstanding teacher as well as a brilliant scholar. Upon his recent death many of these students recounted anecdotes illustrating the powerful impact he had on them as a teacher. Interestingly, many anecdotes that students would tell are stories not about some literary subject, but about the thoughtfulness with which he would teach undergraduate and graduate students alike. One day, in a graduate course, Frye prompted a student to ask a question about the text that they had been assigned to read. The student's question was obviously a very stupid one, making it clear to everyone in class that he had not read the text at all. All class members were holding their breath in total embarrassment for the student who was, of course, mortified. Everyone was afraid that Frye would light into him and tear him to pieces with crushing remarks.

Frye remained silent for a while. Minute after long minute went by. His silence lasted so long that the atmosphere became almost intolerable for everyone in class. Finally, without a trace of irony in his voice, Frye said, 
"that is a very good question, but to answer it I will have to rephrase it." Then he carefully reformulated the student's question and continued to provide a dazzling answer to it. The woman who recounted this anecdote recalled how the entire class almost audibly sighed with pure surprise and utter relief. She said, "Not only did we learn something profoundly valuable, but we also did so in an act of collective love for this man who knew how to keep the students' respect intact and make them love the subject matter at the same time."

Now, of course, some of you may feel that Frye did wrong, that he should have nailed the student who after all had been delinquent in his assignment. But I'd suggest that Frye's tact was effective: no student would likely be remiss again in doing assigned reading. And in the process Frye left the student's sense of self intact. Rather than criticizing, defeating, or preaching he strengthened and enhanced the student's possibility of living up to the example Frye set.

Let me once more raise the question of the title of this talk: Can teaching be taught? Are real teachers found or made? Maybe the dichotomy of the question prevents us from seeing alternative possibilities. If it is true that there exists a pedagogical sphere in human life and that it is possible to enter a pedagogical relation with someone, then maybe we fall into pedagogy not unlike the way we fall in love or find a friend. The exact alchemy of these events is scientifically unexplainable. But just like the mysterious powers of love or friendship, the power of pedagogy can transform or change us and prompt us to aim for a special thoughtfulness in our human relations with children or adults. Understanding such transformations, changes, conversions, alterations requires discourses with magical intentions: discourses that can speak to the head, heart, and body - and thus knowing when a child needs a hug, or a smile, or some praise, or some help, or a change of pace, or a prod of interest, or your undivided attention. As I suggest, this pedagogical relation may be like love or friendship in that it cannot be produced by rational-technical means. But it can be evoked by the right kind of texts, the right kind of experiences.

Exploring a pedagogy of tact not as a technical, but as a thoughtful practice, may increase our sensitivity of how children learn and how they may feel and experience things. For this purpose we must remember what it is like to be a child not only by reminiscing on our own childhood experiences, but also by recollecting what it is like to be a child today and tomorrow. While the daily grind of life in the family or in the school may wear us down at times, we animate our vitality by reminding ourselves of the incredible scope, significance, richness, and challenge of teaching and living with children. Like Northrop Frye, I cannot imagine a more original and meaningful vocation 


\section{University of Alberta}

\section{Notes}

1. This article is the text of a talk presented as the McCalla Lecture at the University of Alberta Faculty of Education, November 13, 1991. This talk was also presented at the Graduate Seminar of Simon Fraser University Faculty of Education, October 25, 1991.

2. Mollenhauer used this picture on his 1983 text Vergessene Zusammenhänge, dealing with culture and pedagogy in an historical context. Through a study of cultural artifacts and artistic sources Mollenhauer explored what significance education can still hold for our time. See also two articles by Mollenhauer in this issue of Phenomenology + Pedagogy.

3. I thank Bas Levering for bringing this book and quote of Anne Tyler to my attention.

3. This is the type of policy pronouncement made recently by the Alberta government, Minister of Education Jim Dinning. Ostensibly it is a reaction by the politician to the perception that Canadian schoolchildren have fallen far behind Japanese and German children in school achievements.

5. A portion of Herbart's first speech is reproduced in Jacob Muth (1982).

6. The best historical reference is probably the small but excellent book on the role of tact in German educational theory by Jacob Muth (1982). I have been guided by several insights on the history and function of tact from Muth's text.

\section{References}

Burms, B., \& de Dijn, H. (1988). Ludwig Wittgenstein. In TELEAC, Meesters van de Westerse Filosofie. The Netherlands: BRT-Instructieve Omroep.

Mollenhauer, K. (1983). Vergeten Samenhang. Meppel: Boom.

Muth, J. (1982). Padagogischer Takt. Essen: Verlagsgesellschaft.

Van Manen, M. (1991). The tact of teaching: The meaning of pedagogical thoughtfulness. Albany, New York: SUNY Press; London, Ont.: Althouse Press.

Van Manen, M. (1990). Researching lived experience: Human science for an action sensitive pedagogy. London, ON: Althouse Press; New York: SUNY Press. 